\title{
Sarah's submissiveness to Abraham: A socio-historic interpretation of the exhortation to wives in 1 Peter 3:5-6 to take Sarah as example of submissiveness
}

Fika J van Rensburg

School of Biblical Studies and Bible Languages North-West University (Potchefstroom Campus)

\begin{abstract}
In 1 Peter 3:5-6 the author of First Peter refers to the holy women of the past who were submissive to their own husbands, and then refers to Sarah who obeyed Abraham and called him master. A socio-historic interpretation of this exhortation to wives in 1 Peter 3:5-6, using Sarah's submissiveness to Abraham as example of submissiveness, is given. This is done in order to approximate the reception of this tradition in First Peter, and the way the letter's first hearers/readers' (specifically the women) understood the author's exhortation, and to establish what the implications of this exhortation are for the role of women in churches today.
\end{abstract}

\section{INTRODUCTION}

A cursory reading of 1 Peter 3:1-6 seems to create hardly any interpretative problems. Closer scrutiny, however, reveals the following puzzling aspects of Peter's argument (cf Michaels 1988:164-165):

1) Abraham as role equivalent of the unbelieving husbands being hostile to their wives' faith.

2) The fact that the use of the title kúpıs invites confusion with a Christian's allegiance to Christ as Lord, especially in the light of all the other uses of Kúpıos in 1 Peter: 1:3,25; 2:3,13; 3:12,15. 


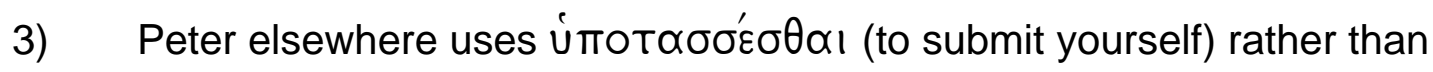

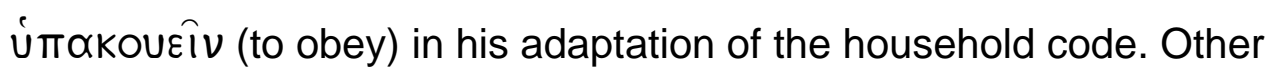
New Testament household codes use úmakouعiv of the obedience of children to fathers (Col 3:20; Eph 6:1) and slaves to masters (Col 3:22; Eph 6:5), but not of wives to husbands. Furthermore, the only other occurrences of the úrøKou-stem is in 1:2, 14, 22, every time referring to Christian conversion or faith in God, not to social relationships.

4) Sarah's remark in Genesis 18:12 hardly seems an example of submission to her lord (as 1 Peter 3:5-6 suggests), but rather amused scepticism at the extravagant promise she has heard.

This paper attempts a socio-historic interpretation of this exhortation to wives in 1 Peter 3:5-6 to take Sarah's submissiveness to Abraham as example of submissiveness, and endeavours in this way to contribute towards solving the puzzling aspects of Peter's argument in 1 Peter 3:1-6.

The paper is outlined as follows:

- $\quad$ The textual context of 1 Peter 3:1-7 is established.

- The context of the reference to the Old Testament figure of Sarah is constructed.

- $\quad$ The probable socio-historic context of the exhortations in 1 Peter 3:1-6 is constructed.

- $\quad$ The tradition and transmission concerning Sarah's submissiveness to Abraham is established.

- A conclusion on the interpretation of Peter's use of Sarah as example is formulated.

- $\quad$ Possible implications of the exhortation in 1 Peter 3:5-6 for Christians in present day societies are suggested.

\section{THE TEXTUAL CONTEXT OF 1 PETER 3:1-7}

The place of 1 Peter 3:1-7 within the whole of the letter can be represented in the following way, showing that 3:1-7 is interpreted to be part of 1 Peter 2:114:19, a third of four exhortations based upon 1 Peter 1:3-12: 


\section{LETTER HEADING}

1:1-2: Author, addressees and greeting

\section{LETTER OPENING}

1:3-12: Praise be to God, the Father of our Lord Jesus Christ; He gave us new birth.

FOUR INFERENCES WITH THE REBIRTH AS BASIS

$\rightarrow$ Inference 1: 1:13-25: Set your hope fully on the grace and there-

fore be holy

$\rightarrow$ Inference 2: 2:1-10: The obligation of a reborn person to grow individually as well as together with fellow-believers

Inference 3: 2:11-4:19: Code of conduct for aliens

2:11-12: The basic exhortation

2:13-17: Relationship with political authorities

$\rightarrow$ 2:18-25: Relationship with employers

3: 1-7 : Relationship with the marriage partner

3: 8-12: Relationship with neighbours in general

3:13-4:19: Attitude towards and reaction to unjust sufferings

$\rightarrow$ Inference 4: 5:1-11: Code of conduct within the church

\section{CONCLUSION}

5:12-14: Conclusion: Purpose, salutations, letter closing

The place of 3:1-7 within the whole of $2: 11-4: 19$ is evident from the following representation, showing that $3: 1-7$ is a third application of the basic

exhortation given in 2:11-12:

The basic exhortation: Be good in all relationships

2:11-12: Since you are aliens and strangers, abstain from natural desires. Be good among the pagans.

Applied to the relationship with the government

2:13-17: Submit yourself to every human authority, for God demands it from you.

Applied to the relationship with employers

$\rightarrow$

2:18-25: Following the example of Christ you even have to submit yourself to unreasonable employers.

Applied to the relationship between marriage partners

3:1-7: Even in a society where women are discriminated against, God's exhortation to married people stays valid.

Applied to the relationship with neighbours in general

- 3:8-12: The key to true joy of life lies in the execution of God's exhortations regarding fellow-human beings.

Applied to the attitude to and reaction on injustice

3:13-4:19: Even if you should suffer for doing what is right, you must see it as commendable before God. 
The argument of 1 Peter 3:1-6 is interpreted to be the following:

- In 3:1 the author exhorts wives to be submissive to their husbands.

- He then states the result of such submissiveness: “... so that, if any of them do not believe the word, they may be won over without words by the behaviour of their wives, when they see the purity and reverence of your lives" (3:1-2).

- He continues: "Your beauty should not come from outward adornment, such as braided hair and the wearing of gold jewellery and fine clothes. Instead, it should be that of your inner self, the unfading beauty of a gentle and quiet spirit, which is of great worth in God's sight" (3:3-4).

- $\quad$ In 3:5-6 he then motivates his exhortation to seek inner beauty, by stating that this is the way holy women of the past put their hope in God and were submissive to their husbands (3:5).

- In 3:6 he mentions Sarah as one example of "holy women of the past". Sarah is thus set up as a model of a wife who fulfils the qualitative requirements of 3:1-4.

\section{SARAH IN THE OLD TESTAMENT}

The reference in 1 Peter 3:5-6 is probably to Genesis 18:12 LXX where Sarah, when she heard the promise of a son, laughed and said: "This has

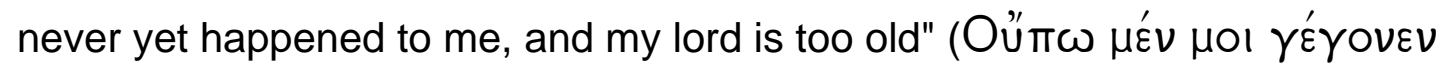

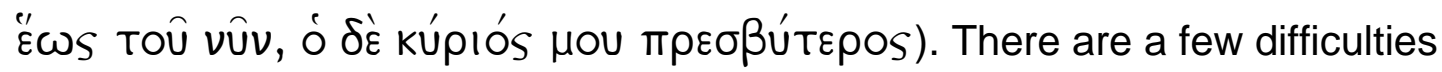
in establishing the exact reference: Sarah only refers to Abraham as her kúpıos; there is no evidence in the Old Testament that she addresses him in this manner. A second problem is that the context in Genesis 18 does not imply obedience to Abraham in any way.

The story of Abraham and Sarah is found in Genesis 11:27-25:11. This story, although part of the larger ancestral history, has its own integrity (Anderson 1988:355). It has its own beginning (the migration of Abraham and Sarai), its own dynamic (their spiritual journey), and its own conclusion (the burial of Abraham and Sarah in the family tomb, the cave of Mahpelah). The theme that unifies the story is God's promises.

In Genesis 11, 12 and 16 Sarah is called Sarai (princess). In Genesis 17:15 it is changed to Sarah, signifying a new reality (Yee 1992:981): the barren Sarah is brought into God's covenantal promise as the mother of many nations and kings (Gn 17:16).

Yee (1992:981) argues convincingly that the narrative about Sarah (and the other matriarchs) is not primarily about the woman herself as 
individual, but rather about her role as legitimate wife and mother of the male successor. She (1992:981) also points to the fact that marriage alliances in Israelite society are endogamous, and that lines of decent are patrilineal. Such endogamous patrilineal relationships may be utilised to control women in the self-interest of their men.

Recent studies show that the biblical stories of the matriarchs follow a literary paradigm whereby the legitimate wife is paired with a rival co-wife who possesses certain characteristics that the other lacks (Brenner 1985, 1986; Cohen 1983; cf Yee 1992:981). Sarah can therefore not be discussed without her complementary person, her maid Hagar.

It seems that Sarah is both victim and victimiser in the patriarchal system in which she lives (Yee 1992:982). She is victim in the sense that the patriarchal system defines her in her capacity to bear sons. The narrative structure spotlights the promise of a son. She is, however, also victimiser in that she mistreats her servant Hagar, and ruthlessly cuts her and her son off from the source of their economic well being.

Genesis 12 and 20 could be the unspoken background of 1 Peter 3:5-6 (Kiley 1987:689-692). There are at least three reasons for this argument:

- $\quad$ Since the first readers/hearers are identified as resident and visiting aliens, the author is drawing on a story of a pioneer of the faith in a foreign land.

- $\quad$ The general acknowledgement by scholars that Abraham's treatment of Sarah is unjust.

- $\quad$ The motifs of beauty and prayers occur in both 1 Peter 3:1-7 and Genesis 20.

This argument seems quite convincing. Abraham and Sarah are indeed portrayed as residing in foreign countries. In Genesis 12 Abraham and Sarah journey through Egypt. Abraham feels that, as the husband of a beautiful wife, the Egyptians will endanger his life unless he presents her to them as his sister. So he asks Sarah to say that she is his sister (in Genesis 20 he actually says so himself). Sarah bows to his wishes. When she is taken to Pharaoh's court and it is discovered that recent ills in his house are the result of his possession of another man's wife, Abraham and Sarah are allowed go safely on their way. 


\section{THE PROBABLE SOCIO-HISTORIC CONTEXT OF THE EXHORTATION}

Much has been written on the position of women and the relationship between marriage partners in the first century AD.

It is sufficient for the present article to point out that the code of submission to the husband was typical not only of Christian and Jewish marriages. Balch (1981:23-31, 33-59) convincingly shows how at least from the time of Plato, and specifically in the era First Peter was written, many documents with examples of exhortations to women to be submissive to their husbands existed.

To quote some Greek author's on the topic, gives one a feeling of authenticity. E.g., Aristotle (Nicomachean Ethics, VIII vii.1), writing about the issues of friendship, makes the following statement concerning the relationship of the husband and wife. It gives an idea of the probable prevalent attitude towards women in marriage relationships.

\begin{tabular}{|c|c|}
\hline 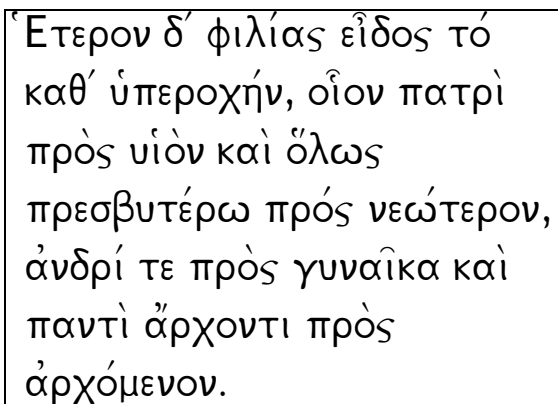 & $\begin{array}{l}\text { But there is a different kind of friendship, which } \\
\text { involves superiority of one party over the other, for } \\
\text { example, the friendship between father and son, } \\
\text { and generally between an older person and a } \\
\text { younger and that between a husband and a wife } \\
\text { and between any ruler and person ruled. }\end{array}$ \\
\hline
\end{tabular}

More or less the same attitude is evident from what Philo (Hypothetica 7.3,5) writes:

\begin{tabular}{|c|c|}
\hline 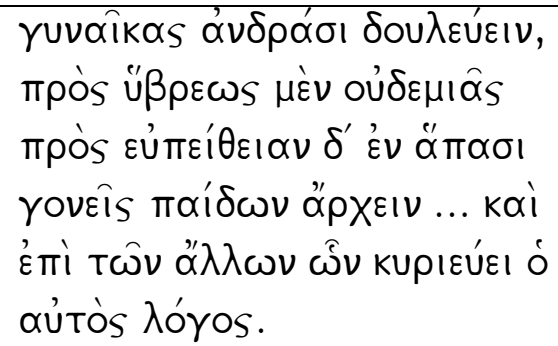 & $\begin{array}{l}\text { Wives must be in servitude to their husbands, a } \\
\text { servitude not imposed by violent ill treatment but } \\
\text { promoting obedience in all things. Parents must } \\
\text { have power over their children ... The same holds } \\
\text { of any other persons over whom he (a man) has } \\
\text { authority ... }\end{array}$ \\
\hline
\end{tabular}

Josephus (Against Apion, II.199) makes a similar statement:

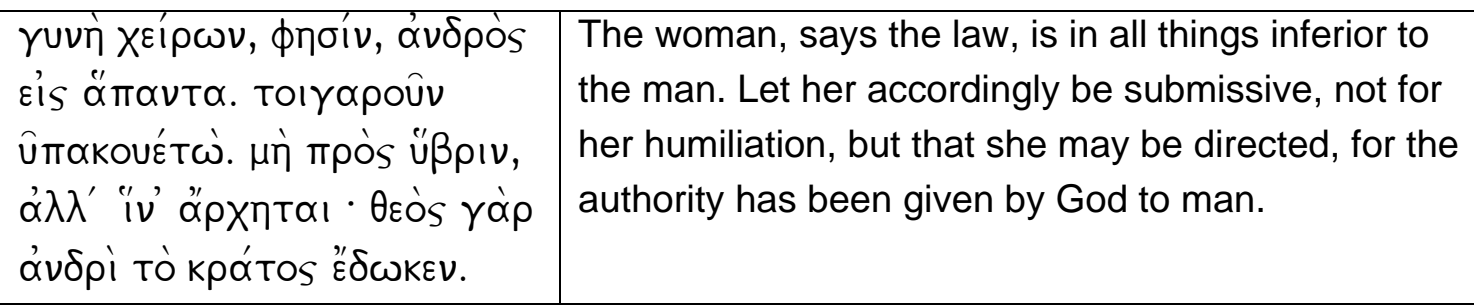


Plutarch (Advice to bride and bridegroom, 140D, 144DE) states very explicitly that the wife may not have a religious identity of her own, but that she must adopt her husband's.

The socio-historic context within which Peter gives his exhortation to wives to be submissive to their husbands, is therefore a patriarchal society, with limited rights to women. It was a society where it was convention and therefore acceptable to discriminate against a wife.

The socio-historic context can therefore be constructed to be the following:

- $\quad$ The superiority of husband over wife is generally accepted and viewed as an integral part of an orderly society.

- $\quad$ In the Christian church women had their equality and human dignity restored and were treated as persons in their own right. This caused tension in many marriages, especially where the husband remained a non-Christian.

- $\quad$ Furthermore, the authorities were very adamant that new religious movements and collegia do not affect the orderly functioning of households and therefore the authority of the state by giving women too much of a say.

- $\quad$ The Christian wives, therefore, found themselves in a difficult position, which explains the need for guidelines for their behaviour towards their husbands. It was important that the husbands should not feel threatened by their wives' newly found freedom, and that society at large should not perceive wives as being not submissive.

This explains why in 1 Peter there are not in the first place general guidelines for marriage (as are found in Eph 5:21-32 and Col 3:18-19). The pericope in 1 Peter is about the plight of the believing wife, should her husband be unreasonable or unbelieving, and the plight of the believing husband towards his wife in a society where unequal treatment of women was not viewed as discrimination, but accepted as general practice.

\section{THE TRADITION AND TRANSMISSION CONCERNING SARAH'S SUBMISSIVENESS TO ABRAHAM}

Sarah's obedience to Abraham (or vice versa) was a matter of some discussion among biblical commentators in the first century AD (cf Sly 1991:126). Some details in the Genesis account of Sarah and Abraham's marriage were embarrassing to men in the Hellenistic age. Sly (1991:127) points out that nowhere else do the LXX use a derivative of "obey" 


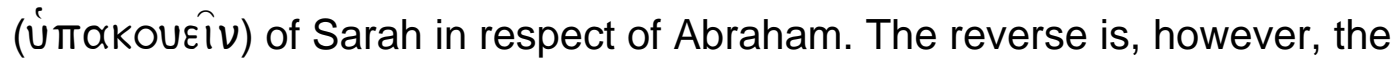
case: Abraham obeys Sarah:

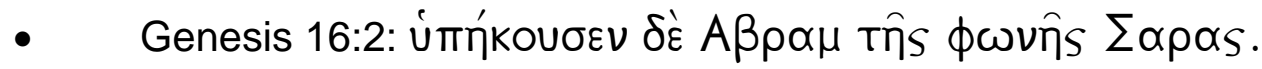
("Abraham hearkened to the voice of Sarah"). The context is Sarah's suggestion that Abraham has a child by Hagar.

- In Genesis 16:6 Abraham's bowing to Sarah's wishes is implied when

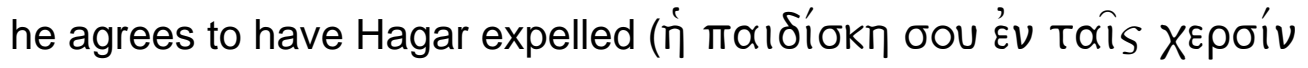

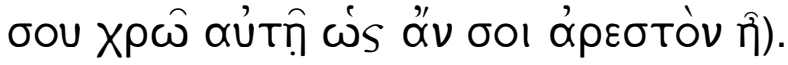

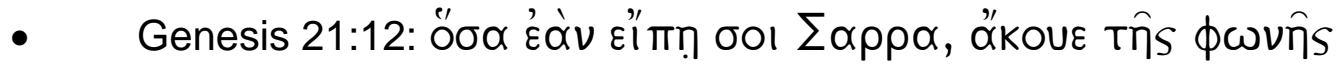

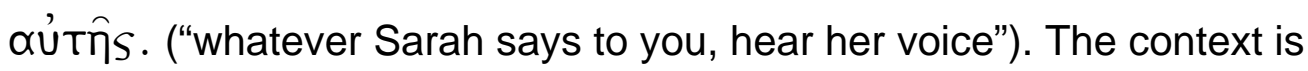
Abraham's distress about Hagar and her boy's relationship with Sarah and Isaac.

Sly (1991:127-128) shows how Philo resorts to several tactics when faced with the scriptural evidence that Abraham obeyed his wife: allegory, denial of Sarah's womanhood/wifehood, and subtle reconstruction of the details of the story. She (1991:129) also shows how Josephus (Antiquities of the Jews I.10.4) retells Genesis $16: 2$ in such a way that it is God's behest that Sarah brings Hagar to Abraham's bed. Bailey (1987:154-179), in a comprehensive study on Josephus' portrayal of the matriarchs, convincingly points out how Josephus hellenized them.

It may be that Peter was deliberate in reinterpreting the story for his own purposes, moulding Sarah into the image of the ideal Hellenistic wife, even at the price of reversing the biblical record.

Rabbinical literature exalted Sarah as being surpassingly beautiful (Megilla 15a) and exceedingly modest (Baba Meșia 87a) (cf also Slaughter 1996:359).

1 Peter 3:5-6 is not the only place in the New Testament where there is reference to Sarah. The traditions in the New Testament regarding Sarah are the following:

- In Romans 4:19 her barrenness highlights Abraham's faith in God's promises.

- $\quad$ Hebrews 11:11 shifts the focus from Abraham to Sarah's own faith in conceiving in her old age.

- $\quad$ Romans 9:6-9 alludes to the conflict between Sarah and Hagar by insisting that not all are children of Abraham because they are his 
descendants. God chose Isaac over Ishmael to be the heir of God's promises.

- In Galatians 4:21-31 Hagar allegorically represents those in slavery under the law, the present Jerusalem. Sarah, on the other hand, is the Jerusalem above, who is free, the mother of the Christian community.

To this list may be added, if one takes the notion of "Sarah's children" as possible analogy of "Abraham's children", also Romans 9:7 ("Nor because they are his descendants are they all Abraham's children. On the contrary, "It is through Isaac that your off spring will be reckoned.") and John 8:39 ( "Abraham is our father," they answered. "If you were Abraham's children," said Jesus, "then you would do the things Abraham did."), especially in the light of Isaiah 51:2 ("... look to Abraham, your father, and to Sarah, who gave you birth").

\section{CONCLUSION}

One should not read too much profound theology into Peter's language (Michaels 1988:165). It seems as if Peter simply ignores the context of Genesis 18:12, and fastens in stead on one word kúpıos. It therefore seems as if Mead (1964:288) is correct in his observation that historical contextuality was not cherished on principle in quoting from or alluding to other sources in New Testament times. The New Testament writer as well as their Palestinian Jewish contemporaries seem to move about in an atmosphere of revealed religion which regards scriptural statements as true both in whole and in various sized parts.

This explains the phenomenon that, while seemingly alluding to Genesis 18:12, the author of First Peter actually has Genesis 12 and 20 in mind, focusing on Sarah's comportment in those chapters (Kiley 1987:692). This establishes her not only as a model of obedience but as a model of those wives who obey their spouses in an unjust and frightening situation in a foreign land or hostile environment.

Sarah, under the hands of Peter, therefore serves as a good example to wives because of her response to her husband (Slaughter 1996:362-363). Several times submitting to her husband (though he was not an unbeliever) meant trusting God in uncertain, unpleasant, and even dangerous situations. Moving with Abraham form Ur to Canaan (Gn 12:1-8) may have been frightening for Sarah. Perhaps even more frightening may have been following her husband to the courts of Pharaoh (Gn 12:10-20) and Abimelech (Gn 20).

It therefore seems as if Peter is very carefully modifying the authoritarian Roman household ethic for the wives (cf Balch 1984:166). Peter 
is thus not merely mirroring society in what he writes in 1 Peter 3:1-7. In a strategic way he gives guidance to his (female) readers to use their freedom in Christ in the way Christ would have (cf $1 \mathrm{Pt} \mathrm{2:21-25).}$

It is now possible to briefly look at the puzzling aspects of Peter's argument, listed in the introduction:

(1) Abraham as role equivalent of the unbelieving husbands being hostile to their wives' faith: The typical freedom in quoting from the Old Testament (and other sources), allows that the focus is not on Abraham's role, but on Sarah's, despite the fact that in the Old Testament context it is the other way around.

(2) The fact that the use of the title kúpıos invites confusion with a Christian's allegiance to Christ as Lord: The title kúpıos was used not only for God, but also as a general title to show respect. Therefore the context is necessary to eliminate any confusion, and in 1 Peter 3:5-6 it is quite clear that the title refers to Abraham.

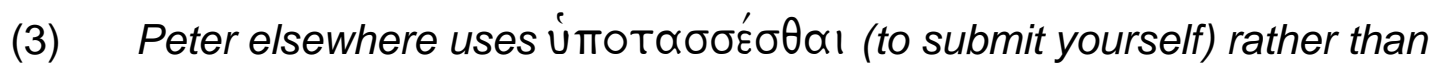
úmaKouEiv (to obey) in his adaptation of the household code: It is clear from Peter's argument that úmakoueiv in this context serves as an

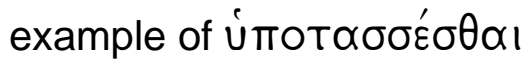

(4) Sarah's remark in Genesis 18:12 seems not at all an example of submission to her lord: The fact that historical contextuality was not cherished on principle in New Testament times, allows that Peter's focus is solely on the title kúpıos, exhibiting in itself the type of attitude Peter wants to elicit from his female readers.

The main issue of 1 Peter 3:1-7 is that Peter wants to show that God's injunction to marriage partners remains valid, even in a society where it is the convention to discriminate against a wife. And this goes for both the wife and the husband.

\section{THE IMPLICATIONS OF THE EXHORTATION IN 1 PETER 3:5-6 FOR CHRISTIANS IN PRESENT DAY SOCIETIES}

When trying to infer the implications of the exhortation in 1 Peter 3:5-6 for Christians today, the starting point should be that 1 Peter 3:1-7 gives guidelines for a very specific situation. It is about the plight of the faithful Christian wife, should her husband be unreasonable or unbelieving. And it is also about the plight of the believing husband towards his wife in a society 
where discrimination against women was accepted not only as general practice, but also as beneficial to the general orderliness of the state.

Another starting point should be the exhortation in Ephesians 5:21

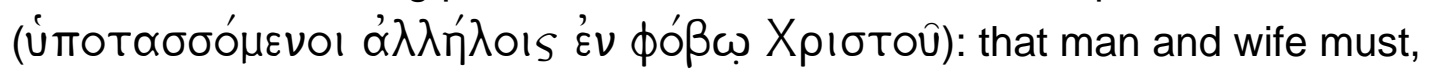
out of respect for Christ, be submissive to one another.

To be submissive towards someone means that, out of love for God, you declare yourself willing to serve that person. When only one party is faithful, the execution of the instruction becomes much more difficult because now it becomes a matter of one-sided submissiveness. Like Christ who submitted himself one-sidedly to death in order for us to be saved, Christians today may also be called to be submissive in a one-sided way, so that others can see Christ in them. Such one-sided submissiveness demands the kind of spiritual power only available to those in whom the Holy Spirit lives and works.

Peter's one example out of the holy women of the "old days" namely Sarah, was powerful for his first readers. They had high respect for Sarah, and would want to be her spiritual off spring. Christians today may not share the high esteem for Sarah. Every Christian, however, would like to have the wisdom to live in such a way in their marriage relationships, that it will be clear that they are children of God (and thus sisters/brothers to Sarah).

The pericope 1 Peter 3:1-7 shows how this happens in a society were it is acceptable that the one sex dominates the other, and where such discrimination is not prohibited by legislation:

- $\quad$ The partner in the Sarah position, the one being dominated, must not be "deterred" by the unreasonableness of their marriage partner. $\mathrm{He} / \mathrm{she}$ must be willing to be submissive in a one-sided way.

- $\quad$ The partner in the Abraham position, being more "privileged", should not use the opportunity to dominate the marriage partner, but should heed the exhortation of 1 Peter 3:7: even if society allows you to be disrespectful, do not use this licence, but show respect. And: even if the partner is weaker, do not dominate.

If all of this happens, First Peter 3:1-7 ends with a promise: Nothing will hinder your prayers.

\section{Works consulted}

Anderson, B W 1988. Abraham, the friend of God. Interpretation 42, 353-366.

Aristotle. Nicomachean ethics. London: Heinemann (1947). (The Loeb Classical Library.) 
Bailey, J L 1987. Josephus' portrayal of the matriarchs, in Feldman, L H \& Hata, G (eds), Josephus, Judaism and Christianity, 154-179. Detroit, MI: Wayne State University Press.

Balch, D L 1981. Let wives be submissive: The domestic code in 1 Peter. Chico, CA: Scholars Press. (SBLMS 26.)

Balch, D L 1984. Early Christian criticism of patriarchal authority: 1 Peter 2:11-3:12. Union Seminary Quarterly Review 39, 161-173.

Brenner, A 1985. The Israelite woman. Sheffield: JSOT Press.

Brenner, A 1986. Female and social behaviour: Two descriptive patterns within the "birth of a hero" paradigm. Vetus Testamentum 36, 257-273.

Cohen, N J 1983. Sibling rivalry in Genesis. Judaism 32, 331-342.

Connock, E B 2000. The exhortation to wives in 1 Peter 3:1-7 to be submissive to their husbands: A socio-historical study. MA Dissertation, Potchefstroom University for Higher Christian Education.

Josephus. The life against Apion, Vol 1. London: Heinemann (1956). (The Loeb Classical Library.)

Josephus [1960]. Complete works, tr by W Whiston. Grand Rapids, MI: Kregel. Kiley, M 1987. Like Sara: The tale of terror behind 1 Peter 3:6. JBL 106, 689-692.

Mead, R T 1964. A dissenting opinion about respect for context in Old Testament quotations. NTS 10, 279-289.

Michaels, J R 1988. I Peter. Waco, TX: Word. (Word Biblical Commentary.)

Philo [1954]. Hypothetica, Vol 11. London: Heinemann. (The Loeb Classical Library.)

Plutarch [1928]. Advice to bride and bridegroom. New York, NY: GP Putnam's Sons. (The Loeb Classical Library.)

Slaughter, J R 1996. Sarah as a model for Christian wives (1 Peter 3:5-6). Bibliotheca Sacra 153, 357-365.

Sly, D I 1991. 1 Peter 3:6b in light of Philo and Josephus. JBL 110, 126-129.

Thurén, L 1995. Argument and theology in I Peter. Sheffield: Sheffield University Press.

Van Rensburg, F J 1992. The outline of 1 Peter: A reconsideration. Ekklesiastikos Pharos 74, 26-41.

Yee, G A 1992. s v Sarah. The Anchor Bible Dictionary. 